\title{
A grazing height target to minimize tiller stem elongation rate in annual ryegrass swards
}

\author{
Altura limite de pastejo para minimizar o alongamento \\ de colmos em pastos de azevém anual
}

\author{
Gabriela Trevisan Santos ${ }^{\mathrm{I}}$ Guilherme Doneda Zanini ${ }^{\mathrm{I}}$ \\ Deisy Andrade PadilhaII André Fischer Sbrissia ${ }^{I^{*}}$
}

\section{ABSTRACT}

Italian ryegrass (Lolium multiflorum Lam) is one of the most cultivated temperate annual forage crop around the world. Despite that, there is little information about the process of stem elongation during its vegetative growth. This information would be useful for grazing management purposes. Thus, the aim of this study was to assess the herbage accumulation and stem elongation rates in annual ryegrass pastures submitted to intermittent stocking. The experimental design used was a completely randomized $2 \times 2$ factorial with three replications. The treatments were defined by the combination of two pre-grazing heights (15 and $25 \mathrm{~cm}$ ) associated with two post-grazing heights (4 and $8 \mathrm{~cm})$. The herbage accumulation rates were higher in pastures with $25 \mathrm{~cm}$ pre-grazing associated with post-grazing heights of $8 \mathrm{~cm}$. However, leaf production rate was only affected by post-grazing height, with higher values being recorded for stubbles heights of $8 \mathrm{~cm}$, regardless of pre-grazing height. Stem elongation rates in annual ryegrass tillers increased rapidly when pastures reached around $18 \mathrm{~cm}$, a condition where there was a relatively low competition for light, suggesting that; 1) pre-grazing heights of 18 to $20 \mathrm{~cm}$ in annual ryegrass could be used as a upper limit for grazing management purposes whether the objective is to minimize stem contribution in accumulated herbage and 2) It seems that stem elongation is as inevitable process (independently of competition for light) and that this could be related to the necessary strength of stems, pseudostems and sheaths to support larger and heavier leaves.

Key words: grazing flexibility, grazing management, sward height, light interception, Lolium multiflorum.

\section{RESUMO}

$O$ azevém anual (Lolium multuflorum Lam) é uma das plantas forrageiras de clima temperado mais cultivadas no mundo. Apesar disso, há poucas informações sobre o processo de alongamento de colmos para essa espécie durante seu crescimento vegetativo. Tal informação seria útil para o manejo mais adequado desta espécie. Assim, o objetivo do presente trabalho foi avaliar o acúmulo de forragem e as taxas de alongamento de colmos em pastos de azevém anual submetidos à lotação intermitente. $O$ delineamento experimental foi completamente casualizado em arranjo factorial $2 \times 2$, com três repetições. Os tratamentos consistiram na combinação de duas alturas em pré-pastejo (15 e $25 \mathrm{~cm})$, associadas com duas alturas de resíduo $(4$ e $8 \mathrm{~cm})$. A maior taxa de acúmulo de forragem foi observada nos pastos manejadas com $25 \mathrm{~cm}$, associadas com alturas de resíduo de $8 \mathrm{~cm}$. Entretanto, a taxa de acúmulo de folhas foi similar para pastos manejados com $8 \mathrm{~cm}$ de residuo, independente da altura em pré-pastejo (15 ou $25 \mathrm{~cm}$ ). A taxa de alongamento de colmos em perfilhos de azevém anual aumentaram rapidamente quando os pastos atingiram uma altura de $18 \mathrm{~cm}$, condição onde havia uma relativa baixa competição por luz, sugerindo que: 1) alturas em pré-pastejo entre 18 e $20 \mathrm{~cm}$ em pastos de azevém anual poderia ser usada como um limite máximo de altura quando o objetivo for minimizar a contribuição de colmos na forragem acumulada; $e$ 2) parece que o alongamento de colmos é um processo inevitável (independente de competição por luz) e isso poderia estar relacionado com a força necessária de colmos, pseudocolmos e bainhas para suportar o peso de folhas cada vez maiores e mais pesadas.

Palavras-chave: flexibilidade de manejo, manejo do pastoreio, altura do pasto, interceptação de luz, Lolium multiflorum.

\section{INTRODUCTION}

Previous studies have shown that canopy height might be an important tool for grazing management purposes (HODGSON, 1985, CARNEVALLI et al., 2006; ZANINI et al., 2012b).

IPrograma de Pós-graduação em Produção Vegetal, Universidade do Estado de Santa Catarina (UDESC), Lages, SC, Brasil.

IIPrograma de Pós-graduação em Ciência Animal, UDESC, Avenida Camões, 2090, 88520-000, Lages, SC, Brasil. E-mail: andre.sbrissia@udesc.br. "Corresponding author. 
This is because this variable includes many structural features that determine the differences in sward architecture with implications for both; successive pasture regrowth and defoliation by grazing animals (FONSECA et al., 2012). CARNEVALLI et al. (2006) conducted a study in Panicum maximum cv. 'Mombaça' swards and suggested that the use of the critical leaf area index (LAI) concept (LAI in which the sward intercepts around $95 \%$ of the incident light) could be used for grazing management purposes in tropical climate grasses. Further, this author found a positive and close relationship between canopy light interception and sward height. Several authors confirmed these findings with others tropical grasses (GIACOMINI et al., 2009; PEDREIRA et al., 2009; ZANINI et al., 2012a) and lead to the concept "target heights" as a grazing management criterion (HODGSON \& Da SILVA, 2004).

The basic principle associated with the interruption of regrowth when the sward intercepts $95 \%$ of the incident light (or its corresponding height) might be attributed to the fact that, from this point, competition for light results in a concomitant increase in senescence and tiller stem elongation rates (BARBOSA et al., 2007) with a negative impact on both; net leaf production (ZANINI et al., 2012a) and instantaneous herbage intake rates by grazing animals (FONSECA et al., 2012).

Although this subject has been recently well explored in some tropical climate grasses, the use of canopy height, as a management criterion in annual ryegrass pastures is still not well established, particularly in the case of intermittent stocking. Among the few studies that used canopy height as a control variable in annual ryegrass, AMARAL et al. (2013) reported that instantaneous herbage intake rate was maximized in swards grazed at $25 \mathrm{~cm}$ (pre-grazing height). Nevertheless, they suggested that lower heights (around $15 \mathrm{~cm}$ ) could also be used with no negative impact to the herbage intake process, since, in both the situations, the swards were not grazed below $10 \mathrm{~cm}$.

Due to its relatively high plasticity (observed by the relatively constant herbage production between 10 to $18.5 \mathrm{~cm}$ heights, when grazed under continuous stocking; PONTES et al., 2004), the present study assumed the central hypothesis that annual ryegrass pastures allow flexibility in herbage production at a relatively wide range of use under a rotational regime, and that there is a upper limit height for this species where there is a rapid increase in stem elongation rate even during its vegetative growth.

\section{MATERIAL AND METHODS}

The approximate geographic coordinates of the experiment site are $27^{\circ} 47^{\prime} \mathrm{S}$ and $50^{\circ} 18^{\prime} \mathrm{W}$, with an approximate altitude of $910 \mathrm{~m}$. The soil is classified as Haplic Cambisol (EMBRAPA, 2006), and the chemical characteristics of the soil before the beginning of the experiment were $\mathrm{pH}$ in $\mathrm{H}_{2} \mathrm{O}, 5.2$; phosphorus $\left(\mathrm{mg} \mathrm{dm}^{-3}\right), 7.5$; potassium $\left(\mathrm{mg} \mathrm{dm}^{-3}\right), 164$; calcium (cmolc dm$\left.)^{-3}\right), 5.1$; magnesium $\left(\mathrm{cmolc} \mathrm{dm}^{-3}\right)$, 3.5; $\mathrm{H}+\mathrm{Al}\left(\mathrm{cmolc} \mathrm{dm}^{-3}\right), 6.7$; and aluminum (cmolc $\left.\mathrm{dm}^{-3}\right), 0.3$. Seeding was performed on June 6 with $40 \mathrm{~kg}$ $\mathrm{ha}^{-1}$ seeds in rows spaced $17 \mathrm{~cm}$ apart in a no tillage system. The climate data of the experimental period were collected from the UDESC/CAV meteorological station and are presented in figure 1 .

The experimental design was a completely randomized $2 \times 2$ factorial with three replications. Treatments were defined by the combination of two pre-grazing heights $(15$ and $25 \mathrm{~cm}$, defined on the basis of preliminary results conducted by AMARAL et al. (2013)) and two post-grazing heights (swards grazed at 4 and $8 \mathrm{~cm}$ ). Despite this author have found that Italian ryegrass should not be grazed at swards heights below $10 \mathrm{~cm}$ (when the objective of grazing management is to optimize instantaneous herbage intake rate), in our experiment we have decided to include a more severe post grazing height to test the plastic limit response of this plant $(4 \mathrm{~cm})$. A single fertilization was carried out on July 27, 2009 (before the assessment period), with the application of $200 \mathrm{~kg} \mathrm{ha}^{-1}$ of nitrogen as ammonium sulfate $(21 \%$ of $\mathrm{N}$ and $24 \%$ of S).

The area with annual ryegrass $\left(200 \mathrm{~m}^{2}\right.$ paddocks) remained ungrazed until August 10, 2009, when all pastures were grazed to their desired post-grazing heights. Assessments began in midAugust (winter) when the swards reached the desired pre-grazing heights and ended in mid-November (spring) before the beginning of the reproductive period of the pastures.

Herbage samples were collected 1 day before grazing when the swards reached their target pre-grazing heights $(15$ or $25 \mathrm{~cm}$ ). In each pasture, three rectangular quadrats of $0.125 \mathrm{~m}^{2}$ were placed at points that represented the average canopy condition of the pasture. After collection, the samples were weighed, mixed with the other samples and subsampled. Fresh samples from each stratum were weighed on a balance (sensitivity of $1 \mathrm{~g}$ ). Two subsamples were separated - one of the subsamples was used to assess the herbage mass and the second was dried by microwave to calculate the stocking rate 


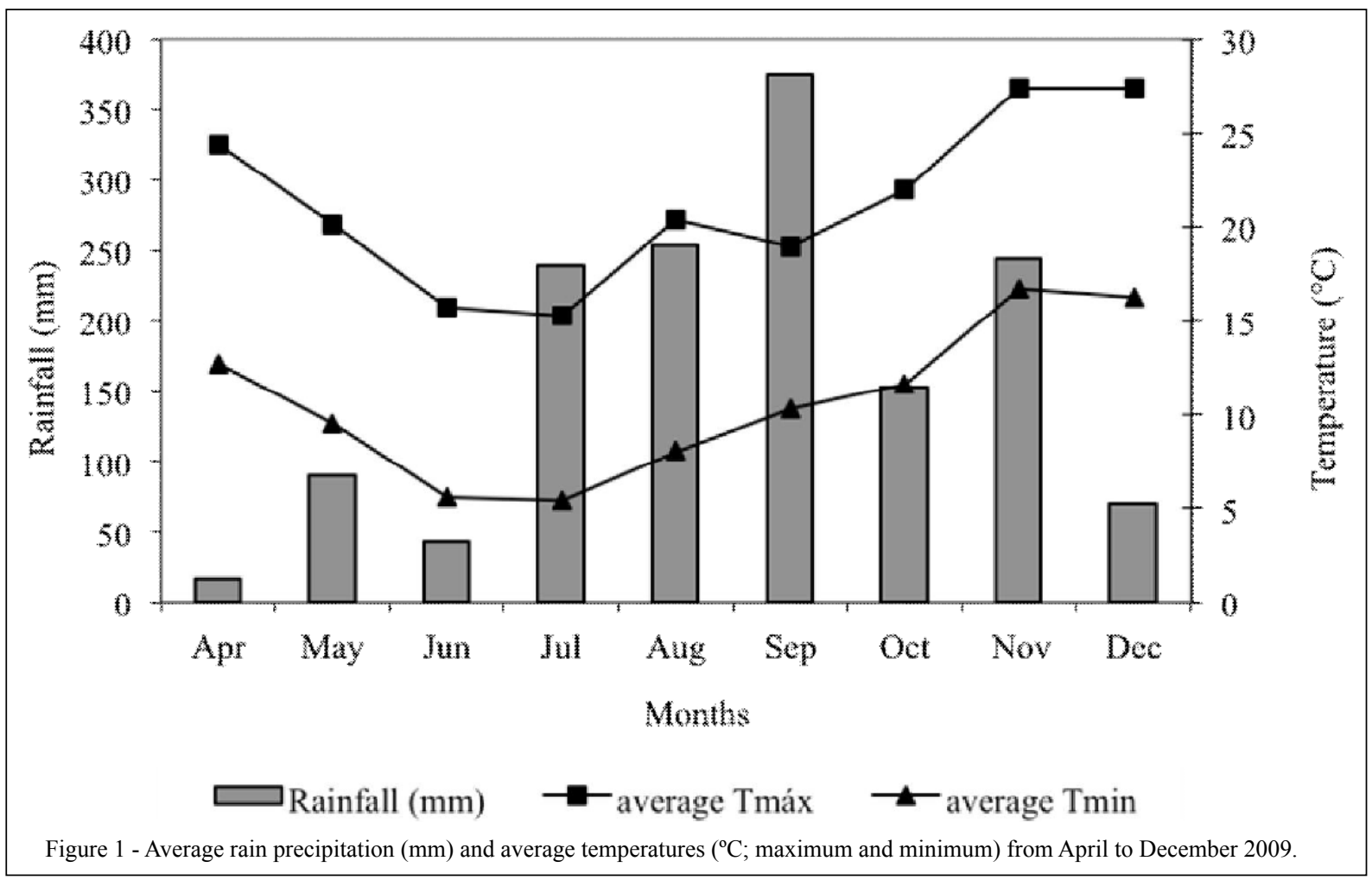

necessary to graze the pastures down to the desired residue targets. The occupation period was calculated to the last one day based on a total herbage intake of $3.0 \%$ of body weight. Pastures were grazed by Texel breed sheep (average body weight of $32 \mathrm{~kg}$ ). The same procedure was performed at post grazing condition to determine post-grazing herbage mass.

Canopy height was determined using a sward stick (BARTHRAM, 1985) by using 50 readings per paddock along 5 transect lines (10 points per transect) in a zigzag pattern. Canopy light interception was monitored twice a week across the regrowth period by using a canopy analysis device (ACCUPAR model LP 80; Decagon Devices $^{\circledR}$, EUA). Light readings were obtained at 6 points that represented the mean condition of swards of each experimental unit: one reading was obtained above the canopy, and five were obtained at the ground level.

Morphogenic and structural characteristics were assessed in 20 tillers per experimental unit. In these tillers, leaves were numbered and classified as intact or defoliated leaves; growing leaves (with no visible ligule); expanded leaves (visible ligule), and senescent leaves. The tillers were analyzed, and the positive variations along the leaf blade were recorded. In the case of senescent leaves, the length of leaf blade considered was from the ligule to the point to which the senescence had progressed. The stem length (stem + sheaths) was measured as the distance between the soil level and the ligule of the last fully-grown leaf. These data were used to calculate the leaf elongation, leaf senescence, and stem elongation rates.

The tiller population density (TPD) was determined by counting the total number of live tillers inside poly-vinyl chloride (PVC) rings of $10 \mathrm{~cm}$ in diameter, located at places that represented the mean condition of the swards (at pre-grazing). Herbage accumulation was obtained by multiplying the tiller population density by the leaf and stem elongation rates (LER and SER) and by the leaf senescence rate (LSR) and specific weight of components ( $\mathrm{g}$ of dry matter $(\mathrm{DM}) \mathrm{cm}^{-1}$ of leaf or stem + pseudostem) (DAVIES, 1993).

The data were analyzed using the "MIXED" procedures of statistical package SAS ${ }^{\circledR}$. The covariance matrix was selected according to the Akaike information criterion (AIC), and the grazing cycles were considered as repeated measures. Thus, detecting the effects of the major causes of variation was possible (pre-grazing and post-grazing heights, as well as the interaction between them). Tukey test was used to compare means among treatments, with a 5\% significance level. The regression analysis was

Ciência Rural, v.46, n.1, jan, 2016. 
performed using the PROC NLIN procedure of SAS statistical package.

\section{RESULTS AND DISCUSSION}

Since the time for pastures to reach the pre-grazing height targets varied, the number and interval between grazing cycles also varied (Table 1). Accordingly, pastures grazed at $15 \mathrm{~cm}$ pre-grazing and $8 \mathrm{~cm}$ post-grazing heights presented four grazing cycles, and the remaining pastures three grazing cycles (Table 1). In the present study, the assessments were completed while the swards were still in a vegetative state, since one of the main objectives was to analyze stem elongation before tillers could begin reproduction. The light interception did not reach $95 \%$ of incident radiation in any of the treatments during the assessment period (maximum $85.4 \%$, on average, of light interception (LI) in swards grazed at $25 \mathrm{~cm})$. These data are different from those reported by AMARAL et al. (2013). In their study, the annual ryegrass pastures at $25 \mathrm{~cm}$ had already intercepted $95 \%$ of incident light. This discrepancy might be explained by the seeding method (in rows), which probably induced the growth of less dense canopies. One of the indications of relatively low competition for light among plants was the similarity between treatments $(\mathrm{P}>0.05$, Table 1$)$ for the values of tiller population density (TPD), since it should be expected that shorter swards $(15 \mathrm{~cm})$ had presented a greater amount of smaller tillers and vice-versa (MATTHEW et al., 1995). The values (5640 tillers $\mathrm{m}^{-2}$, on average) were greater than those reported by CAUDURO et al. (2006) and DUCHINI et al. (2014), who also used annual ryegrass under rotational stocking. Since assessments were performed in $10 \mathrm{~cm}$ diameter $\mathrm{PVC}$ rings placed directly on the seeding rows, the values obtained practically did not consider the empty spaces between the rows, which probably caused an overestimation of the values. Moreover, the $\mathrm{N}$ fertilization carried out at the beginning of the experiment $\left(200 \mathrm{~kg} \mathrm{ha}^{-1}\right.$ of $\mathrm{N}$ ) certainly stimulated high tillering of the ryegrass, which along with a relatively low competition for light even in swards grazed at a greater height, preventing the death of tillers due to self-shading. Thus, since the TPD did not vary between treatments, any changes in herbage production between the treatments resulted directly from variations in the growth and senescence processes of tissues of individual tillers.

The pre- and post-grazing heights impacted the herbage accumulation rate, where the highest values were observed in pastures grazed at $25 \mathrm{~cm}$ and at a post-grazing height of $8 \mathrm{~cm}$ (Table 2). However, pastures at $25 \mathrm{~cm}$ also showed the highest rates of stem accumulation, which contributed, on average, 28\% for accumulated herbage compared to $17 \%$ in pastures grazed at $15 \mathrm{~cm}$ (Table 2). Nevertheless, when only leaf accumulation rates were considered, the results showed only postgrazing effect, where higher production was found in pastures grazed at $8 \mathrm{~cm}$, regardless of the initial height (Table 2). Since the senescence rates were relatively low, it did not affect the overall pattern of responses. The decrease in leaf production in pastures grazed at $4 \mathrm{~cm}$ might be attributed to the low amounts of leaves remaining after grazing, which might have delayed the process of reconstruction of the leaf area (PARSONS et al., 1988). Since leaf production was practically insensitive to the defoliation heights used $(15$ and $25 \mathrm{~cm})$, it is suggestive that this plant might have a relatively high flexibility in relation to its leaf-producing capacity, since it is not grazed below $8 \mathrm{~cm}$.

Table 1 - Pre- and post-grazing heights $(\mathrm{cm})$, light interception (\%) grazing cycles, and tiller population density (tiller $\cdot \mathrm{m}^{-2}$ ) in annual ryegrass pastures under intermittent stocking.

\begin{tabular}{|c|c|c|c|c|c|c|c|c|}
\hline \multirow{3}{*}{ Variables } & \multicolumn{4}{|c|}{--Height (cm)-1- } & \multirow{3}{*}{ SEM $^{*}$} & \multicolumn{3}{|c|}{ - } \\
\hline & \multicolumn{2}{|c|}{-_--_- } & \multicolumn{2}{|c|}{ 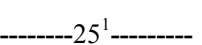 } & & \multirow[b]{2}{*}{ Pre } & \multirow[b]{2}{*}{ Post } & \multirow[b]{2}{*}{ Int Pre*Post } \\
\hline & $4^{2}$ & $8^{2}$ & $4^{2}$ & $8^{2}$ & & & & \\
\hline Pre-grazing height & 15.8 & 16.7 & 25.8 & 25.3 & - & - & - & - \\
\hline Post-grazing height & 4.7 & 7.6 & 5.6 & 8.3 & - & - & - & - \\
\hline Number of grazing cycles & 3 & 4 & 3 & 4 & - & - & - & - \\
\hline Average interval between grazing (days) & 15 & 13 & 19 & 19 & - & - & - & - \\
\hline Pre-grazing light interception & 57.3 & 64.4 & 84.9 & 86.0 & 1.86 & $* * *$ & NS & NS \\
\hline Tiller population density & 5509 & 5909 & 5573 & 5579 & 671 & NS & NS & NS \\
\hline
\end{tabular}

${ }^{1}$ Pre-grazing heights, ${ }^{2}$ Post-grazing heights, ${ }^{3}$ Pre $=$ Pre-grazing height effect, Post $=$ Post-grazing height effect, Pre Post $=$ grazing interaction, Standard error of the mean. 
Table 2 - Forage mass $\left(\mathrm{kg} / \mathrm{DM} \cdot \mathrm{ha}^{-1}\right)$, proportion of leaves and stems $(\%)$, total and net growth rate, senescence rate $\left(\mathrm{kg}\right.$ of $\left.\mathrm{DM} \cdot \mathrm{ha} \cdot \mathrm{day}{ }^{-1}\right)$ in annual ryegrass pastures under intermittent stocking.

\begin{tabular}{|c|c|c|c|c|c|c|c|c|}
\hline \multirow{3}{*}{ Variables } & \multicolumn{4}{|c|}{ 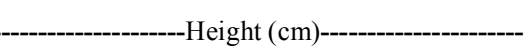 } & \multirow{3}{*}{ SEM $^{*}$} & \multicolumn{3}{|c|}{-----------Effects----------- } \\
\hline & . & & -- & & & \multirow[b]{2}{*}{ Pre } & \multirow[b]{2}{*}{ Post } & \multirow[b]{2}{*}{ Int } \\
\hline & $4^{2}$ & $8^{2}$ & $4^{2}$ & $8^{2}$ & & & & \\
\hline Pre-grazing forage mass & $980 \mathrm{c}$ & $1400 \mathrm{~b}$ & $2113 \mathrm{a}$ & $1990 \mathrm{a}$ & 96.7 & NS & NS & **** \\
\hline Post-grazing forage mass & 630 & 970 & 790 & 1120 & 100 & NS & ${ }^{* * *}$ & NS \\
\hline$\%$ of leaves pre-grazing & $51 \mathrm{a}$ & $43 \mathrm{~b}$ & $41 \mathrm{~b}$ & $43 \mathrm{~b}$ & 2.3 & NS & NS & ${ }^{* * *}$ \\
\hline$\%$ of stems pre-grazing & 21 & 21 & 34 & 32 & 1.8 & $* * *$ & NS & NS \\
\hline$\%$ of leaves post-grazing & $12 \mathrm{~b}$ & $20 \mathrm{a}$ & $8 \mathrm{c}$ & $9 \mathrm{c}$ & 1.1 & $* * *$ & $* * *$ & $* * *$ \\
\hline$\%$ of stems post-grazing & 31 & 34 & 35 & 38 & 4.8 & NS & NS & NS \\
\hline Total growth rate & 89 & 103 & 102 & 139 & 8.15 & $* * *$ & $* * *$ & NS \\
\hline Leaf senescence rate & $2.1 \mathrm{~b}$ & $1.6 \mathrm{~b}$ & $1.9 \mathrm{~b}$ & $4.3 \mathrm{a}$ & 0.76 & $\mathrm{NS}$ & NS & ${ }^{* * *}$ \\
\hline Stem accumulation rate & $16 \mathrm{c}$ & $18 \mathrm{c}$ & $26 \mathrm{~b}$ & $42 \mathrm{a}$ & 3.75 & NS & NS & $* * *$ \\
\hline Leaf accumulation rate & 74 & 86 & 76 & 88 & 5.5 & NS & ${ }^{* * *}$ & NS \\
\hline$\%$ of stems in accumulated forage & 17 & 18 & 26 & 30 & 3.03 & *** & NS & NS \\
\hline
\end{tabular}

${ }^{1}$ Pre-grazing heights, ${ }^{2}$ Post-grazing heights, ${ }^{3}$ Pre $=$ Pre-grazing height effect, Post $=$ Post-grazing height effect, Int $=$ Pre and post grazing interaction, ${ }^{*}$ Standard error of the mean. Letters indicate differences between treatments only in the case of interaction.

Although the data showed similarity in leaf production of swards grazed at 15 or $25 \mathrm{~cm}$ (associated with post-grazing height of $8 \mathrm{~cm}$ ), the proportion of stems in the accumulated herbage of the latter accounted for nearly $30 \%$ of the total production, suggesting the existence of a point from $15 \mathrm{~cm}$, where stem elongation undergoes a rapid increase. Figure 2 shows the functional relationship between stem elongation rates and sward heights. The data presented are from the $25 \mathrm{~cm}$ treatments associated with postgrazing height of $8 \mathrm{~cm}$ for the three assessment cycles. In this figure, each plot corresponded to the average stem elongation rate calculated as the variation in two consecutive evaluations of stem + pseudostem length. This evaluation was performed when sward heights were, on average, with $8,12,17,21$ and $25 \mathrm{~cm}$. Thus, it was only possible to obtain stem elongation rates from $12 \mathrm{~cm}$ swards onwards and for $8 \mathrm{~cm}$ swards SER was assumed to be zero. Interestingly, from a sward height of $17.7 \mathrm{~cm}$, there was a marked increase in stem elongation rates (slope of 0.00942 for the first step and that of 0.06589 for the second step of stepwise regression). This increase by almost 7 times in stem elongation rate from this height was directly responsible for the largest proportion of stems observed in the accumulated herbage in pastures grazed at $25 \mathrm{~cm}$ pre-grazing height (Table 2). These results are quite similar to those reported by MIGUEL et al. (2012) who found a sheath + pseudostem proportion around $34 \%$ in $35 \mathrm{~cm}$ italian ryegrass swards (measured in terms of length of extended tillers) during vegetative growth. Further, there was a significant lengthening of the stem when light interception was considerably lower (Table 2) than that corresponding to the critical LAI (95\% LI), suggesting that other factors might be involved in this process. The rapid accumulation of stems (Table 2, Figure 2) around $18 \mathrm{~cm}$ might be associated with a progressive increase in leaf length. Thus, in order to support the weight and distribution of large leaves that remain upright, ryegrass tillers must also invest in stem formation regardless of the shading caused by the larger leaves in the canopy. According to NIKLAS (2004), the aerial portions of a plant are submitted to force units (F), such as gravity, wind, and increment in size and weight of organs. These forces require that plants allocate assimilates for self-sustenance during the growth stage, in addition to providing photosynthetic structures that guarantee the assimilation of biomass (BALLARÉ et al., 1991). Thus, the stem elongation process might be an inevitable condition, even under low herbage mass conditions (low forage volumetric density, as observed by MIGUEL et al., 2012), without the occurrence of high levels of competition for light. Moreover, recent studies have shown that instantaneous herbage intake rate is maximized when pastures are grazing down at levels of defoliation of $40 \%$ of initial height (FONSECA et al., 2012; MEZZALIRA et al., 2014), regardless of grass specie. Thus, despite of leaf production being relatively constant from 15 to $25 \mathrm{~cm}$, it seems that sward heights targets around $20 \mathrm{~cm}$ in annual ryegrass would be a compromise between high leaf production with high herbage intake rates, since on using higher pre-grazing heights 


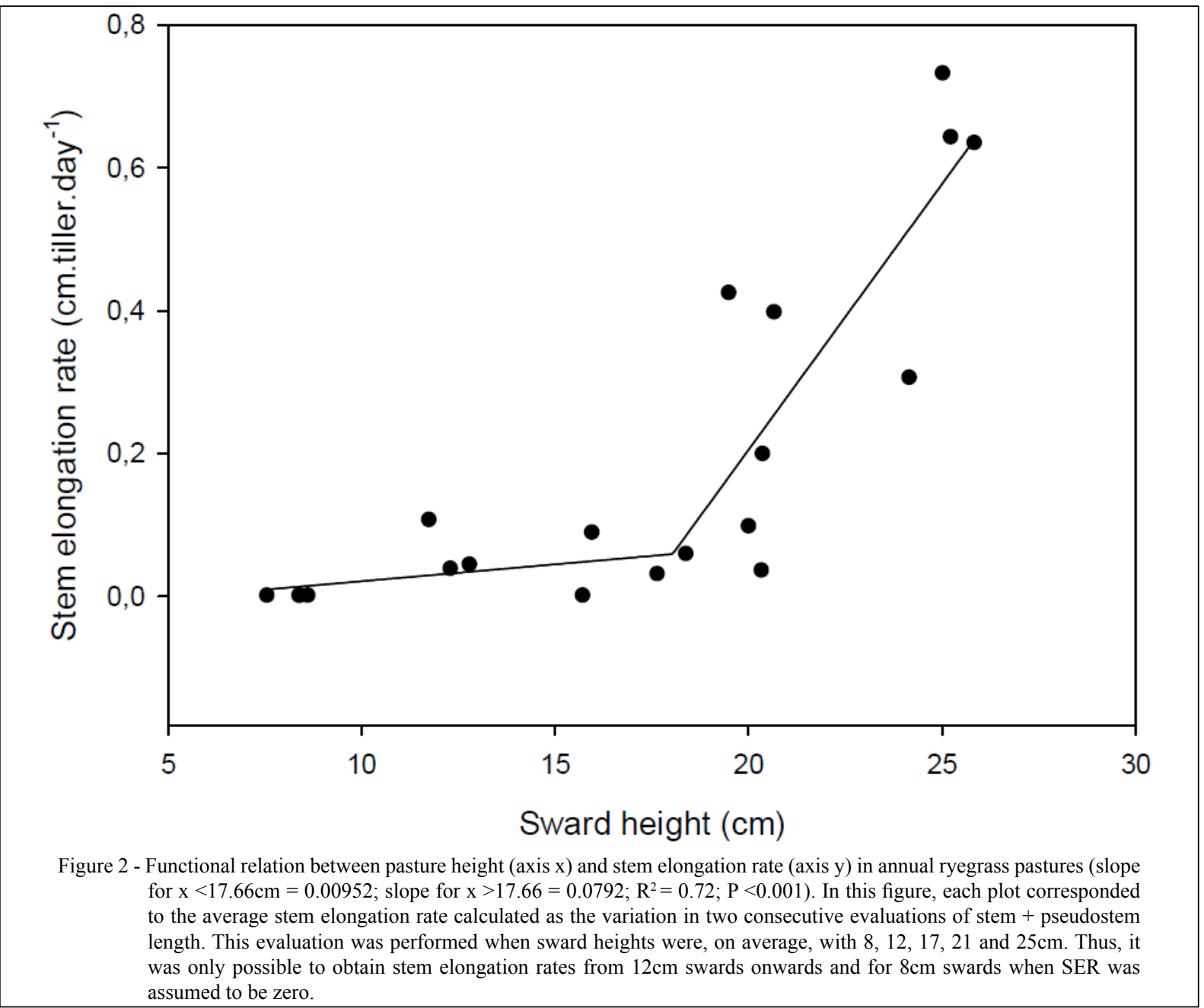

the remaining stubble after grazing would present a great amount of stems that will become progressively larger in subsequent regrowth, which could lead to a deterioration in sward structure with negative impact for herbage intake and production.

\section{CONCLUSION}

Annual ryegrass pastures present a relatively high flexibility for forage production under intermittent stocking and might be grazed at heights between 15 and $25 \mathrm{~cm}$ pre-grazing without reduction in leaf production, provided the post-grazing heights above $8 \mathrm{~cm}$.

Sward targets for annual ryegrass of 18$20 \mathrm{~cm}$ at pre-grazing during its vegetative growth could minimize stem contribution in accumulated herbage since tiller stem elongation rates increase fairly rapidly in pastures from $18 \mathrm{~cm}$, even under a relative low-level competition for light.

\section{ACKNOWLEDGEMENTS}

We thank Coordenação de Aperfeiçoamento de Pessoal de Nível Superior (CAPES) for the scholarship and Fundação de Amparo à Pesquisa e Inovação do Estado de Santa Catarina (FAPESC) for funding this research (Grant number: 16257/2007-4).

\section{REFERENCES}

AMARAL, M.F. et al. Sward structure management for a maximum short-term intake rate in annual ryegrass pastures. Grass and Forage Science, v.66,n.2, p.271-277,2013. Available from: $<$ http://onlinelibrary. wiley.com/doi/10.1111/j.1365-2494.2012.00898.x/abstract>. Accessed: May 22, 2015. doi: 10.1111/j.1365-2494.2012.00898.x.

BALLARÉ, C.L. et al. On the opportunity cost of the photosynthate invested in stem elongation reactions mediated by phytochrome. Oecologia, v.86, p.561-567, 1991. Available from: <http://http:// link.springer.com/article/10.1007\%2FBF00318323\#page-1>. Accessed: May 22, 2015. doi: 10.1007/BF00318323.

BARBOSA, R.A. et al. Tanzânia grass subjected to combinations of intensity and frequency of grazings. Pesquisa Agropecuaria 
Brasileira, v.42, n.3, p.329-340, 2007. Available from: <http:// http://www.scielo.br/scielo.php?script=sci arttext\&pid=S0100204X2007000300005>. Accessed: May 22, 2015. doi: 10.1590/ S0100-204X2007000300005.

BARTHRAM, G.T. Experimental techniques: the HFRO sward stick. In: The Hill Farming Research Organization Biennial Report 1984/1985. Penicuik: HFRO, 1985. p.29-30.

CARNEVALLI, R.A. et al. Herbage production and grazing losses in Panicum maximum cv. 'Mombaça' under four grazing managements. Tropical Grasslands, v.40, p.165-176, 2006. Available from: $<$ http://www.tropicalgrasslands.asn.au/Tropical $\% 20$ Grasslands\%20Journal\%20archive/Abstracts/Vol_40_2006/ Abs_40_03_2006_pp165_176.htm >. Accessed: May 22, 2015.

CAUDURO, G.F. et al. Morphogenetic and structural traits of italian ryegrass (Lolium multiflorum Lam.) sward managed under different grazing intensities and methods. Revista Brasileira de Zootecnia, v.35, n.4, p.1298-1307, 2006. Available from: <http:// www.scielo.br/scielo.php?script $=$ sci_arttext\&pid $=$ S1516359820 $06000500007 \& \operatorname{lng}=$ pt\&nrm=iso $>$. Accessed: May 22, 2015. doi: $10.1590 /$ S1516-35982006000500007.

DAVIES, A. Tissue turnover in the swards. In: DAVIES, A. et al. (Eds.). Swards measurement handbook. 2.ed. Reading: British Grassland Society, 1993. p.183-216.

DUCHINI, P.G. et al. Tiller size/density compensation in temperate climate grasses grown in monoculture or in intercropping systems under intermittent grazing. Grass and Forage Science, v.60, p.655-665, 2014. Available from: <http://onlinelibrary.wiley.com/ doi/10.1111/gfs.12095/abstract>. Accessed: May 22, 2015. doi: $10.1111 /$ gfs. 12095

EMBRAPA. Sistema brasileiro de classificação de solos. 2.ed. Rio de Janeiro: Embrapa Solos, 2006. 306p.

FONSECA, L. et al. Management targets for maximizing the shortterm herbage intake rate of cattle grazing in Sorghum bicolor. Livestock Science, v.145, p.205-211, 2012. Available from: $<$ http:// www.sciencedirect.com/science/article/pii/S1871141312000595>. Accessed: May 22, 2015. doi: 10.1016/j.livsci.2012.02.003.

GIACOMINI, A.A. et al. Components of the leaf area index of marandu palisadegrass swards subjected to strategies of intermittent stocking. Scientia Agricola, v.66, n.6, p.721-732, 2009. Available from: <http://www.scielo.br/scielo.php?pid=S010390162009000600002\&script=sci_arttext $>$. Accessed: May 22, 2015. doi: 10.1590/S0103-90162009000600002.

HODGSON J. The significance of sward characteristics in the management of temperate sown pastures. In: PROCEEDINGS OF THE $15^{\text {th }}$ INTERNATIONAL GRASSLAND CONGRESS, The Science Council of Japan, Nishi Nasuno, Japan. Tokyo: 1985. p.31-34

HODGSON, J.; DA SILVA, S.C. Sustainability of grazing systems: goals, concepts and methods. In: LEMAIRE, G. et al. (Eds.).
Grassland ecophysiology and grazing ecology. Cambridge: CAB, Wallingford, United Kingdom, 2004. p.1-13.

MEZZALIRA, J.C. et al. Behavioural mechanisms of intake rate by heifers grazing swards of contrasting structures. Applied Animal Behavior Science, v.153, p.1-9, 2014. Available from: $<$ http://www.appliedanimalbehaviour.com/article/S01681591(13)00321-3/abstract>. Accessed: May 22, 2015. doi: 10.1016/j.applanim.2013.12.014.

MIGUEL, M.F. et al. Pasture characteristics of Italian ryegrass and milk production under different management strategies. Pesquisa Agropecuaria Brasileira, v.47, p.863868, 2012. Available from: <http://www.scielo.br/scielo. php? script $=$ sci arttext\&pid=S0100-204X2012000600018\&lng $=$ pt\&nrm=iso $>$. Accessed: May 22, 2015. doi: 10.1590/S0100204X2012000600018

NIKLAS, K.J. Plant allometry: is there a grand unifying theory? Biological Reviews, v.79, p.871-889, 2004.

PARSONS, A.J. et al. Use a model to optimize the interaction between frequency and severity of intermittent defoliation and to provide a fundamental comparison of the continuous and intermittent defoliation of grass. Grass and Forage Science, v.43, p.49-59, 1988. Available from: <http://onlinelibrary.wiley.com/ doi/10.1111/j.1365-2494.1988.tb02140.x/abstract>. Accessed: May 22, 2015. doi: 10.1111/j.1365-2494.1988.tb02140.x.

PEDREIRA, B.C. et al. Herbage accumulation during regrowth of Xaraés palisadegrass submitted to rotational stocking strategies. Revista Brasileira de Zootecnia, v.38, p.618-625, 2009. Available from: <http://www.scielo.br/scielo.php?pid=S151635982009000400005\&script=sci_arttext $>$. Accessed: May 22, 2015. doi: 10.1590/S1516-35982009000400005.

PONTES, L.S. et al. Biomass flows in Italian ryegrass pastures (Lolium multiflorum Lam.) managed under different sward height. Revista Brasilera de Zootecnia, v.33, p.529-537, 2004. Available from: <http://www.scielo.br/scielo.php?pid=S151635982004000300002\&script $=$ sci_arttext $>$. Accessed: May 22, 2015. doi: 10.1590/S1516-35982004000300002.

ZANINI, G.D. et al. Frequencies and intensities of defoliation in Aruana guinea grass swards: accumulation and morphological composition of forage. Revista Brasileira de Zootecnia, v.41, p.905-913, 2012a. Available from: <http://www.scielo.br/scielo. php? script $=$ sci arttext\&pid $=$ S1516-35982012000400011\&lng $=$ en $\& n r m=i s o>$. Accessed: May 22, 2015. doi: 10.1590/S151635982012000400011 .

ZANINI, G.D. et al. Distribution of stem in the vertical structure of Aruana guinea grass and Annual rygrass pastures subjected to rotational grazing by sheep. Ciencia Rural, v.42, n.5, p.88288, 2012b. Available from: <http://www.scielo.br/scielo. php? script $=$ sci_arttext\&pid=S0103-84782012000500020\&lng $=$ en\&nrm=iso $>$. Accessed: May 22, 2015. doi: 10.1590/S010384782012000500020 